\title{
Jurnal IImiahManajemenUbhara
}

\section{ANALISIS DETERMINAN COMPLETENESS OF FINANCIAL STATEMENT DISCLOSURE}

\author{
Lusiana'; Noegrahini Lastiningsih² \\ Universitas Pembangunan Nasional "Veteran" Jakarta1,2 \\ Lusiana1026@gmail.com"; noegrahini.lastiningsih@gmail.com
}

\begin{abstract}
ABSTRAK
Penelitian ini bertujuan untuk menguji faktor-faktor yang mempengaruhi kelengkapan pengungkapan laporan keuangan. Populasi dalam penelitian ini adalah perusahaan manufaktur yang terdaftar di Bursa Efek Indonesia (BEI) dengan periode 2016-2018. Teknik penentuan sampel menggunakan metode probability sampling adalah cluster sampling. Jumlah sampel sebelum outlier adalah 180 data yang dikumpulkan dan kemudian setelah outlier adalah 161 data yang memenuhi syarat sebagai sampel. Metode analisis data penelitian ini adalah analisis regresi linier berganda dengan taraf signifikansi 5\% dengan bantuan pemrograman data menggunakan SPSS versi 25 untuk dianalisis dalam penelitian ini. Hasil penelitian ini menunjukkan bahwa leverage, struktur kepemilikan, tipe auditor dan umur perusahaan tidak berpengaruh terhadap kelengkapan pengungkapan laporan keuangan. Sedangkan ukuran perusahaan berpengaruh terhadap kelengkapan pengungkapan laporan keuangan dan leverage, struktur kepemilikan, tipe auditor, ukuran perusahaan dan umur perusahaan berpengaruh terhadap kelengkapan pengungkapan laporan keuangan.
\end{abstract}

Kata kunci : Kelengkapan pengungkapan laporan keuangan, leverage, struktur kepemilikan, tipe auditor, ukuran perusahaan dan umur perusahaan

\section{DETERMINANT ANALYSIS OF COMPLETENESS OF FINANCIAL STATEMENT DISCLOSURE}

\begin{abstract}
This study aims to examine the factors that influence the completeness of financial statement disclosures. The population in this study are manufacturing companies listed on the Indonesia Stock Exchange (IDX) for the period 20162018. The technique of determining the sample using probability sampling method is cluster sampling. The number of samples before the outlier is 180 data collected and then after the outlier is 161 data that qualifies as a sample. The data analysis method of this research is multiple linear regression analysis with a significance level of 5\% with the help of data programming using SPSS version 25 to be analyzed in this study. The results of this study indicate that leverage, ownership structure, type of auditor and age of the company do not influence the completeness of financial statement disclosure. While the size of the company affects the completeness of financial statement disclosure and
\end{abstract}


leverage, ownership structure, type of auditor, company size and age of the company affects the completeness of financial statement disclosure.

Keywords: Completeness of financial statement disclosure, leverage, ownership structure, auditor type, company size and company age

Diterima: 16 Maret 2020; Direvisi: 31 Maret 2020; Diterbitkan: 30 April 2020

\section{PENDAHULUAN}

Indonesia masih termasuk dalam kategori pasar negara berkembang sehingga membuat tingkat pengungkapan laporan keuangan pada perusahaan di Indonesia diharapkan dapat terus ditingkatkan sebagai upaya transparansi publik, seiring dengan hal tersebut investor terus menuntut adanya pengungkapan yang tepat waktu dan dapat dipercaya karena adanya tuntutan ini pemerintah telah merespons dengan membuat peraturan mengenai pengungkapan yang lengkap dan wajar serta terus meningkatkan pengawasan terhadap praktik pengungkapan.

Jenis pengungkapan yang diatur oleh OJK dibedakan menjadi 2 jenis yaitu pengungkapan wajib (mandatory disclosure) dan pengungkapan sukarela (voluntary disclosure) dimana pengungkapan wajib merupakan pengungkapan yang mengharuskan perusahaan untuk mengungkapkan laporan keuangan sesuai dengan peraturan pemerintah, hal ini diatur dalam peraturan tentang standar pengungkapan informasi bagi perusahaan yang telah melakukan penawaran umum dan perusahaan publik diatur dalam peraturan OJK No. 29 POJK.04 2016 tentang laporan tahunan emiten atau perusahaan publik. Laporan tahunan menjadi analisis fundamental bagi tiap pemakai laporan keuangan oleh karena itu laporan keuangan tidak boleh memberikan informasi yang menyesatkan dan mencantumkan butir-butir penjelasan atas nilai-nilai yang tercantum dalam laporan keuangan. Dilansir dari IDX Channel dalam beberapa hal seringkali perusahaan tidak mengungkapkan informasi laporan keuangan dengan benar salah satunya yang terjadi pada PT. Hanson International yang telah ditetapkan OJK melakukan ketidaklengkapan pengungkapan terhadap laporan keuangan dengan tidak mengungkapkan nilai perjanjian jual beli kavling siap bangun yang nilainya material sebesar 5,6 miliar pada laporan keuangan tahun 2016 yang mana PT. Hanson mengakui pendapatan tersebut berdasarkan metode akrual penuh akan tetapi perusahaan tersebut tidak mengungkapkan perjanjian pengikatan jual beli kavling siap bangun di perumahan serpong kencana pada tahun 2016 yang mana akibat pengungkapan yang tidak memadai ini mengakibatkan laporan keuangan menjadi overstated yang nilainya material sebesar 613M hal tersbut dikarenakan perusahaan tidak mengungkapkan secara rinci mengenai angka tersebut sehingga angka tersebut berdampak pada kesesatan informasi pengguna laporan keuangan, selain itu Sherly Jokom sebagai akuntan dari rekan pada KAP Purwantono Sungkoro dan Surja yang merupakan member dari Ernst \& Young Global Limited mendapatkan sanksi dari OJK karena dinilai telah melanggar standar auditing dan kode etik auditor sebagaimana sanski yang dijatuhkan adalah pembekuan izin selama 1 tahun yaitu STTD.

Pada kasus ini direktur utama sekaligus pemegang saham di PT. Hanson yaitu Benny Tjokro dinyatakan bersalah, seperti diketahui sebelumnya PT. Hanson pernah diberikan pinjaman oleh Benny Tjokro sebesar 408,8 miliar pada tahun 2011 yang mana akhirnya perusahaan dinilai tidak mampu untuk 
mengembalikan pinjaman tersebut hingga akhirnya utang tersebut dikonversi menjadi kepemilikan saham Benny Tjokro sebesar 10\%. Setelah mencatatkan keuntungan atau laba bersih sebesar Rp 70,71 miliar di tahun 2016 akan tetapi di tahun 2017 perusahaan mencatatkan rugi bersih sebesar $\mathrm{Rp}$ 122,66 miliar, setelah OJK mewajibkan restatement pada laporan keuangan perusahaan hal ini menjadi berbanding terbalik dimana di tahun 2016 perusahaan menjadi tercatat rugi sebesar Rp 210,51 miliar sedangkan di 2017 menjadi laba sebesar Rp 158,56 miliar.

Industri manufaktur merupakan salah satu industri yang menjadi pilar penting dalam laju pertumbuhan ekonomi di Indonesia, di tengah ancaman resesi ekonomi global yang diperkirakan akan terjadi pada tahun 2020 membuat pemerintah terus mendorong pertumbuhan industri manufaktur melihat industri manufaktur masih berada di kisaran $5 \%$ saja menurut data Bank Indonesia. Industri pengolahan atau manufaktur mencatatkan pertumbuhan pada triwulan I tahun 2018 sebesar 4,50 persen, lebih besar dengan pertumbuhan pada tahun sebelumnya yaitu 4,28 persen. Sektor manufaktur pada kuartal pertama tahun ini merupakan penyumbang kontribusi terbesar dengan mencapai 20,27 persen terhadap perekonomian nasional (kemenperin.go.id).

Dipilihnya sektor maunfaktur adalah karena sektor manufaktur terdiri dari banyak sektor industri seperti basic industry, consumer goods dan miscellaneous industry yang memiliki karakteristik berbeda-beda. Sehingga perbedaan karakteristik ini akan berpengaruh terhadap sejauh mana kelengkapan pengungkapan pada laporan keuangan. Sektor manufaktur juga menjadi sektor yang paling banyak diminati oleh investor serta pemilihan sektor manufaktur juga bertujuan untuk melihat seberapa besar tingkat konsumtif masyarakat Indonesia. Selama ini sanksi yang diberikan oleh OJK atas pelanggaran terhadap kelengkapan pengungkapan laporan keuangan dinilai masih belum tegas karena hanya berupa denda, dimana denda tersebut jika dinilai dari sisi perusahaan merupakan nilai yang kecil disbanding perusahaan harus mengungkapkan informasi yang akan membahayakan dan diketahui publik sehingga sampai dengan Mei 2019 tercatat 107 perusahaan yang melakukan pelanggaran.

\section{LANDASAN TEORI}

\section{Completeness of Financial Statement Disclosure}

Teori keagenan muncul karena adanya perbedaan kepentingan yang terjadi anatara agent dan principal dimana agent selalu berusaha untuk mendapat keuntungan bagi dirinya sendiri sedangkan principal menuntut agent untuk melaporkan setiap informasi yang terjadi dalam perusahaan (Pratiwi, 2015). Implikasi teori agency dalam penelitian ini yaitu bahwa teori agency berkaitan dengan completeness of financial statement disclosure karena asimetri informasi yang timbul dari teori agency menyebabkan kurangnya informasi yang didapat oleh pihak principal karena principal hanya menerima informasi yang dialporkan dari agent saja sedangkan agent memiliki banyak informasi mengenai perusahaan. Sehingga agency problem yang timbul akibat perbedaan kepentingan dapat dikurangi melalui pengungkapan informasi yang lengkap dan relevan.

Teori signalling adalah teori yang mengemukakan bagaimana sinyal yang harus diinformasikan oleh perusahaan kepada pengguna laporan keuangan. Dalam hal ini manajemen memberikan sebuah sinyal berupa informasi apa yang sudah dilakukan manajemen dalam pengelolaan perusahaan untuk merealisasikan keinginan para pemegang saham (Neliana, 2017). Teori signalling merupakan perbuatan yang dilakukan oleh manajemen untuk memberikan informasi kepada stakeholder mengenai kinerja dan prospek perusahaan (Fitriani et al. 2016). Strategi yang dibuat perusahaan untuk memberikan sinyal kepada para pengguna laporan keuangannya adalah berupa promosi atau informasi. 
Completeness of financial statement disclosure adalah suatu ketetapan yang mewajibkan perusahaan untuk mengungkapkan informasi yang ada dalam laporan keuangan secara relevan dengan tujuan untuk menghasilkan pelaporan yang berkualitas sehingga informasi yang ada dalam laporan keuangan menghasilkan informasi yang akurat dan menciptakan kondisi pasar modal yang efisien (Hery, 2018 hlm.115). Menurut Ghozali \& Chariri (2014 hlm.408) mendefinisikan disclosure adalah pemberitahuan atas hal-hal informasi yang dinilai penting dan memiliki manfaat bagi para pemakai laporan keuangan, informasi tersebut harus lengkap, jelas serta dapat menggambarkan kejadian-kejadian yang terjadi di dalam perusahaan.

Completeness of Financial Statement Disclosure secara sederhana dapat didefinisikan sebagai penyampaian informasi (the release of information). Pengungkapan laporan keuangan merupakan suatu media pertanggungjawaban perusahaan kepada investor yang berguna untuk menciptakan efisiensi optimal pada pasar modal (Astina, 2017). Kelengkapan dinilai merupakan salah satu bentuk kualitas, kualitas merupakan salah satu faktor penting dalam atribut pengungkapan informasi. Banyak penelitian yang menunjukkan bahwa kelengkapan suatu laporan keuangan dapat dinilai dari indeks item yang berasal dari peraturan OJK No. 29 POJK.04 2016 dimana kelengkapan pengungkapan yang disajikan akan dihitung berdasarkan item-item yang diungkapkan sesuai dengan standar item-item yang harus diungkapkan.

Menurut peraturan OJK No. 29 POJK.04 2016 terdapat dua jenis pengungkapan, antara lain:

1. Pengungkapan Wajib (mandatory disclosure). Merupakan pengungkapan minimum yang harus diungkapkan atau disyaratkan oleh standar akuntansi yang berlaku (kewajiban perusahaan). Jika perusahaan tidak bersedia untuk mengungkapkan secara sukarela maka berbeda dengan pengungkapan wajib dimana perusahaan harus mengungkapkan sesuai dengan yang telah diatur. Pengungkapan wajib yang diwajibkan oleh bapepam memuat 73 item pengungkapan informasi laporan tahunan.

2. Pengungkapan Sukarela (voluntary disclosure). Dalam hal ini perusahaan bebas mengungkapkan item-item yang perlu diungkapkan yang dianggap perusahaan relevan untuk diinformasikan. Pengungkapan ini berupa butir-butir yang dilakukan sukarela oleh perusahaan. Dalam pengungkapan suakrela terdiri dari 33 item.

\section{Leverage}

Leverage adalah penggunaan utang perusahaan untuk membiayai asset perusahaan dengan harapan mendapat tingkat pengembalian berupa laba karena perusahaan dalam menjalankan kegiatan operasinya membutuhkan dana dari pihak lain dalam rangka memaksimalkan laba. Menurut Sinurat \& Sembiring (2016) leverage adalah penggunaan utang untuk aktivitas perusahaan. Sehingga rasio leverage dapat diartikan sebagai penggunaan dana dari pihak ketiga untuk membiayai kegiatan operasional perusahaan. Hery (2014 hlm.162) mendefinisikan leverage adalah penggunaan asset perusahaan yang dibiayai dengan utang. Hal ini bahwa perusahaan yang mempunyai tingkat leverage yang tinggi akan membutuhkan biaya pengawasan yang tinggi hal ini berhubungan dengan penyediaan informasi yang luas dan komprehensif akan memerlukan biaya yang tinggi pula oleh karena itu perusahaan yang memiliki tingkat leverage akan berusaha menyediakan informasi yang lebih luas dan lengkap. Sejalan dengan biaya yang telah dikeluarkannya maka perusahaan dengan leverage tinggi akan

lebih banyak mengungkapkan informasiinformasi dibanding dengan perusahaan yang memiliki tingkat leverage rendah. 


\section{Struktur Kepemilikan}

Perusahaan memiliki struktur kepemilikan yang berbeda-beda pada perusahaannya, suatu struktur kepemilikan akan bergantung pada tujuan perusahaan. Pada penelitian ini struktur kepemilikan yang digunakan adalah kepemilikan institusional. Sebuah struktur kepemilikan dalam suatu perusahaan bergantung pada seberapa besar porsi yang dimilikinya untuk dapat mengendalikan perusahaan. Kepemilikan institusional adalah kepemilikan yang dimiliki oleh sebuah badan atau institusi (Purwanti \& Kalbuana, 2016). Kepemilikian institusional adalah kepemilikan yang dimiliki oleh institusi,badan atau perusahaan lainnya yang umumnya memiliki porsi mayoritas sehingga dapat mempengaruhi keputusan manajemen (Sinurat \& Sembiring, 2016).

\section{Tipe Auditor}

Menurut Ananda (2015) mendefinisikan tipe auditor adalah sebuah dimensi yang diraih oleh auditor atas suatu prestasinya sehingga tipe auditor dibedakan menjadi big four dan non big four. Reputasi KAP akan menggambarkan cerminan dari kualitas auditor tersebut, karena KAP yang bereputasi baik mempunyai komitmen lebih besar untuk mempertahankan kualitas auditnya sehingga laporan keuangan yang dihasilkan menjadi andal,terpercaya dan bebas dari salah saji. Hidayat (2017) mendefinisikan tipe auditor adalah suatu skala atas reputasi auditor yang didapat karena auditor memiliki reputasi yang baik dalam artian telah memperoleh prestasi dan kepercayaan publik atas nama besarnya, karena perusahaan yang diaudit oleh big four dan yang terafiliasi dengan big four akan mempertahankan kualitas auditnya sehingga akan lebih luas dalam mengungkapkan laporan keuangan.

\section{Ukuran Perusahaan}

Menurut Larasati et al (2018) ukuran perusahaan didefinisikan sebagai pengukur besaran, dimensi, atau kapasitas dari suatu perusahaan, hal ini mencerminkan apakah sebuah perusahaan besar atau kecil yang mana ukuran perusahaan dapat dilihat dari nilai total aktiva, penjualan bersih, dan kapitalisasi pasar. Sedangkan menurut (Suryanto, 2017) ukuran perusahaan adalah skala yang dapat mengukur suatu perusahaan dengan melihat ukuran pendapatan, total asset dan jumlah modal, semakin besar ukuran perusahaan yang akan mencerminkan keadaan perusahaan semakin baik.

Menurut Shehata et al. (2014) ukuran perusahaan memiliki pengaruh terhadap completeness of financial statement disclosure yaitu semakin besarnya perusahaan di mata masyarakat akan dituntut untuk mengungkapkan informasi yang lebih lengkap dibanding dengan perusahaan yang berukuran kecil. Dalam penelitian Purwanti \& Kalbuana (2016) menyatakan hubungan ukuran perusahaan dengan kelengkapan pengungkapan laporan keuanagn (completeness of financial statement disclosure) dijelaskan melalui teori keagenan (Jensen \& Meckling, 1976). Dalam hubungan keagenan yang terjadi antara principal dan agent, telah membebani manajer untuk mempertanggungjawabkan sumber daya yang dikelolanya. Perusahaan yang berukuran besar akan mengungkapkan informasi yang lebih banyak dibanding perusahaan kecil sebagai upaya mengurangi biaya keagenan (Jensen \& Meckling, 1976).

\section{Umur Perusahaan}

Hidayat (2017) mendefinisikan umur perusahaan adalah seberapa lama perusahaan telah berdiri dan terdaftar di Bursa Efek Indonesia (BEI) sebagai perusahaan go public. Menurut Astina (2017) umur perusahaan adalah pengelompokkan perusahaan berdasarkan lamanya listing di bursa. Sedangkan menurut (Fitrianti et al., 2017) umur perusahaan adalah penggambaran seberapa lama perusahaan beroperasi hingga perusahaan tersebut dapat mempertahankan eksistensinya dalam dunia bisnis. Iklim bisnis yang semakin ketat juga perubahan teknologi yang juga berdampak pada dunia industri mempengaruhi manajemen perusahaan dalam mengelola dan mengatur 
strategi terhadap perkembangan dunia industri dan usahanya.

\section{Kerangka Pemikiran}

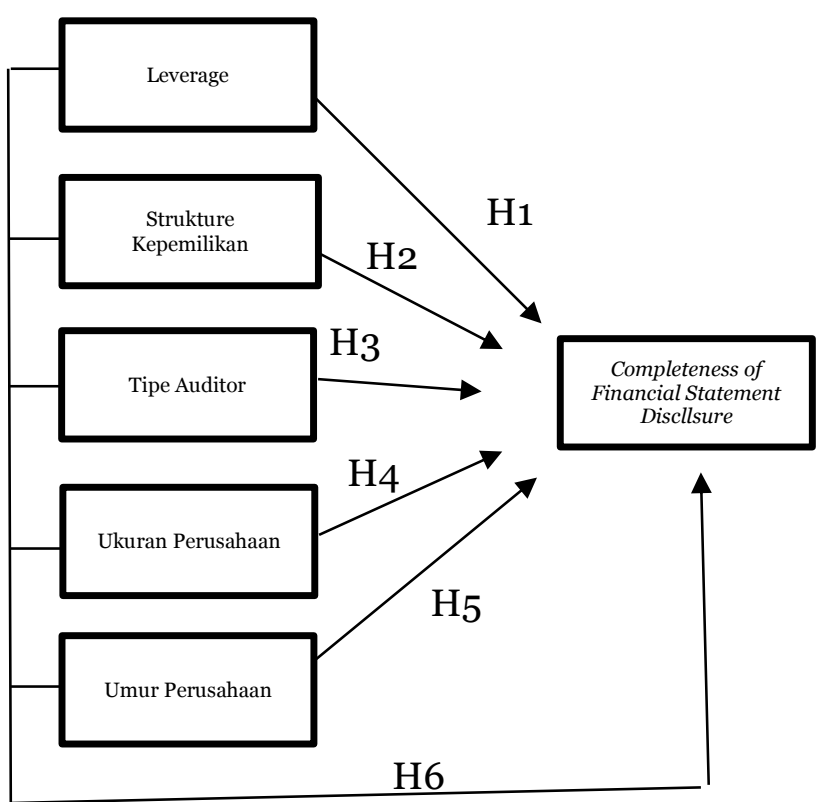

Gambar 1. Kerangka Penelitian

\section{Hipotesis}

H1: Ada pengaruh leverage terhadap completeness of financial statement disclosure;

H2: Ada pengaruh struktur kepemilikan terhadap completeness of financial statement disclosure;

H3: Ada pengaruh tipe auditor terhadap completeness of financial statement disclosure;

$\mathrm{H}_{4}$ : Ada pengaruh ukuran perusahaan terhadap completeness of financial statement disclosure;

$\mathrm{H}_{5}$ : Ada pengaruh umur perusahaan terhadap completeness of financial statement disclosure;

H6: Ada pengaruh leverage, strukture perusahaan, tipe auditor, ukuran perusahaan dan umur perusahaan terhadap completeness of financial statement disclosure;

\section{METODE PENELITIAN}

Populasi yang akan menjadi subjek pada penelitian ini adalah seluruh perusahaan manufaktur yang terdaftar di Bursa Efek Indonesia (BEI) periode 2016, 2017 dan 2018 berjumlah 426. Metode pengambilan sampel dalam penelitian ini menggunakan cluster sampling dimana cluster sampling adalah jenis dari metode probability sampling diperoleh data 161. Metode penelitian kualitatif dengan uji $\mathrm{t}$ dan F melalui software SPSS.

\section{HASIL DAN PEMBAHASAN}

Tabel 1. Pembagian Sampel

\begin{tabular}{lc}
\hline Keterangan & Sampel \\
\hline $\begin{array}{l}\text { Perusahaan manufaktur yang terdaftar secara } \\
\text { berturut-turut selama 2016-2018 }\end{array}$ & 142 \\
\hline Jumlah tahun penelitian & 3 \\
\hline Jumlah data & 426 \\
\hline $\begin{array}{l}\text { Jumlah data yang tidak tersedia selama 3 } \\
\text { tahun berturut-turut }\end{array}$ & $(63)$ \\
\hline $\begin{array}{l}\text { Jumlah data yang tidak terpilih berdasarkan } \\
\text { cluster sampling }\end{array}$ & $(183)$ \\
\hline Jumlah data sebelum outlier & 180 \\
\hline Jumlah data yang terkena outlier & $(19)$ \\
\hline Jumlah data setelah outlier & 161 \\
\hline
\end{tabular}

Sumber: Data dioleh oleh Peneliti

Tabel 2. Hasil Uji T

\begin{tabular}{lccc}
\hline & $\mathrm{B}$ & $\mathrm{t}$ & Sig \\
\hline (Constant) & 0,349 & 3,411 & 0,001 \\
\hline LEV & $-0,013$ & $-0,839$ & 0,403 \\
\hline KSI & 0,014 & 0,584 & 0,560 \\
\hline KAP & $-0,002$ & $-0,137$ & 0,891 \\
\hline SIZE & 0,019 & $\mathbf{5 , 4 6 7}$ & $\mathbf{0 , 0 0 0}$ \\
\hline AGE & $-0,002$ & $\mathbf{- 2 , 9 3 2}$ & $\mathbf{0 , 0 0 4}$ \\
\hline
\end{tabular}

Sumber: Data dioleh oleh Peneliti

Berdasarkan pada hasil uji statistik $t$, diketahui bahwa $t$ hitung leverage adalah sebesar -0,839 dengan tingkat signifikansi sebesar 0,403. Maka dapat disimpulkan bahwa Ho1 diterima dan Ha1 ditolak. Hal ini berarti bahwa leverage tidak berpengaruh signifikan terhadap completeness of financial statement disclosure. 
Berdasarkan pada hasil uji statistik $t$, diketahui bahwa t hitung struktur kepemilikan yang diukur dengan kepemilikan institusional adalah sebesar 0,584 dengan tingkat signifikansi sebesar 0,560. Maka dapat disimpulkan bahwa $\mathrm{Ho2}$ diterima dan $\mathrm{Ha} 2$ ditolak. Hal ini berarti bahwa struktur kepemilikan tidak berpengaruh signifikan terhadap completeness of financial statement disclosure.

Berdasarkan pada hasil uji statistik t, diketahui bahwa t hitung tipe auditor adalah sebesar -0,137 dengan tingkat signifikansi sebesar 0,891. Maka dapat disimpulkan bahwa Ho3 diterima dan Ha3 ditolak. Hal ini berarti bahwa tipe auditor tidak berpengaruh signifikan terhadap completeness of financial statement disclosure.

Berdasarkan pada hasil uji statistik $t$, diketahui bahwa $t$ hitung ukuran perusahaan adalah sebesar 5,467 dengan tingkat signifikansi sebesar 0,ooo. Maka dapat disimpulkan bahwa Ho4 ditolak dan Ha4 diterima. Hal ini berarti bahwa ukuran perusahaan berpengaruh terhadap completeness of financial statement disclosure.

Berdasarkan pada hasil uji statistik t, diketahui bahwa $\mathrm{t}$ hitung umur perusahaan adalah sebesar -2,932 dengan tingkat signifikansi sebesar 0,004. Maka dapat disimpulkan bahwa Ho5 diterima dan Ha5 ditolak. Hal ini berarti bahwa umur perusahaan tidak berpengaruh terhadap completeness of financial statement disclosure.

Nilai F hitung sebesar 10,208 lebih besar dari $\mathrm{F}$ tabel yaitu 2,43 dengan nilai signifikansi sebesar 0,000 atau lebih kecil dari 0,005. Dengan demikian dapat disimpulkan bahwa secara simultan seluruh variabel dalam penelitian ini berpengaruh terhadap completeness of financial statement disclosure.

\begin{tabular}{llllll} 
Tabel 5. Uji F & & \\
\hline $\begin{array}{l}\text { Sum of } \\
\text { Squares }\end{array}$ & Df & Mean & Square & F & Sig.
\end{tabular}

\begin{tabular}{cccccc}
\hline Regression & 0,191 & 5 & 0,038 & 10,208 &, $000^{\mathrm{b}}$ \\
\hline Residual & 0,58 & 155 & 0,004 & & \\
\hline Total & 0,771 & 160 & & & \\
\hline
\end{tabular}

Sumber: Data dioleh oleh Peneliti

Berdasarkan tabel 6 dapat dilihat bahwa nilai Adjusted R Square sebesar 0,248 atau $24,8 \%$. Hal ini menunjukkan bahwa variabel completeness of financial statement disclosure dapat dijelaskan oleh variabel leverage, struktur kepemilikan, tipe auditor, ukuran perusahaan dan umur perusahaan sebesar 24,8\% dari 100\% sedangkan sisanya sebesar $75.2 \%$ dijelaskan oleh faktor-faktor lain yang tidak diteliti dalam penelitian ini.

Tabel 6. $R$ Square

\begin{tabular}{cccr}
\hline R & R Square & $\begin{array}{c}\text { Adjusted R } \\
\text { Square }\end{array}$ & $\begin{array}{c}\text { Std. Error of } \\
\text { the Estimate }\end{array}$ \\
\hline 0,498 & 0,248 & 0,223 & 0,0611616 \\
\hline
\end{tabular}

Sumber: Data diolah oleh Peneliti

\section{Pembahasan}

\section{Leverage Terhadap Completeness of Financial Statement Disclosure}

Hasil penelitian menunjukkan bahwa tingkat leverage perusahaan tidak menjadi dasar atas besar kecilnya tingkat kelengkapan laporan keuangan perusahaan karena baik perusahaan yang memiliki tingkat leverage diatas 50\% dan dibawah 50\% sama-sama mengungkapkan laporan keuangan yang dipersyaratkan oleh OJK.

Hal ini dibuktikan oleh perusahaan PT. MULTI PRIMA SEJAHTERA Tbk (LPIN) pada tahun 2018 yang memiliki tingkat leverage yang rendah yaitu sebesar 0,0929 dan memiliki skor completeness of financial statement disclosure sebesar 73,97\% selain itu hal tersebut juga dapat dibuktikan oleh perusahaan PT. POLYCHEM INDONESIA Tbk (ADMG) pada tahun 2018 yang memiliki tingkat leverage yang rendah yaitu sebesar 0,1315 dan memiliki skor completeness of financial statement disclosure 
di atas 60\% yaitu sebesar 94,52\%, serta perusahaan PT. INDOCEMENT TUNGGAL PRAKARSA Tbk (INTP) yang memiliki tingkat leverage sebesar 0,1331 dan memiliki skor completeness of financial statement disclosure sebesar $91,78 \%$ yang mengartikan bahwa nilai leverage perusahaan rendah tidak mengartikan perusahaan tidak lengkap dalam mengungkapkan laporan keuangannya.

Situasi ini dapat pula dijelaskan bahwa kewajiban-kewajiban perusahaan merupakan kesepakatan bersama antara pihak kreditur dan perusahaan sehingga yang menjadi pertimbangan kreditur atas pemberian dana adalah seperti karakteristik perusahaan, kondisi ekonomi, posisi ekuitas, kemampuan dalam memenuhi kewajiban jangka panjangnya. berarti kelengkapan pengungkapan pada laporan keuangan tidak bergantung pada besar kecilnya tingkat leverage. Hal ini sejalan dengan penelitian Shehata et al. (2014), Halim \& Sampurno (2015), Fitriani et al. (2016), Sinurat \& Sembiring (2016), Purwanti \& Kalbuana (2016) serta penelitian dari Astina (2017) yang menyatakan bahwa leverage tidak berpengaruh terhadap completeness of financial statement disclosure, namun berlawanan dengan penelitian Devi \& Suardana (2014), Pratiwi (2015), Wahyuningsih et al. (2016), Alim \& Ida (2018) serta Larasati et al. (2018) yang menyatakan bahwa leverage berpengaruh signifikan terhadap completeness of financial statement disclosure.

\section{Struktur Kepemilikan terhadap Completeness of Financial Statement Disclosure;}

Hasil penelitian menunjukkan bahwa tingkat kepemilikan institusional yang tinggi tidak menjamin suatu perusahaan akan lebih lengkap dalam mengungkapkan laporan keuangannya karena umumnya kepemilikan institusional akan lebih memperhatikan pada rasio-rasio keuangan penting perusahaan, pihak institusi tidak begitu tertuju pada pengungkapan yang lengkap akan tetapi lebih kepada hasil akhir dari suatu laporan keuangan sebagai bahan evaluasi dan dasar pengambilan keputusan.

Hal ini dibuktikan oleh perusahaan yang memiliki kepemilikan institusional yang rendah dibawah 20\% akan tetapi memiliki skor completeness of financial statement disclosure yang tinggi yaitu pada PT. SAT NUSAPERSADA Tbk (PTSN) yang tidak memiliki kepemilikan institusional atau sebesar o,ooo dan memiliki skor completeness of financial statement disclosure sebesar 0,8630 atau 86,30\% pada tahun 2017, selain itu pada PT. GUNAWAN DIANJAYA STEEL Tbk (GDST) yang memiliki kepemilikan institusional sebesar 0,0213 atau sebesar 2,13\% dan memiliki skor completeness of financial statement disclosure sebesar 0,8767 atau $87,67 \%$ pada tahun 2018 yang mengartikan bahwa besar kecilnya kepemilikan institusional dalam suatu perusahaan tidak berpengaruh pada kelengkapan pengungkapan laporan keuangan perusahaan. Hal ini sejalan dengan penelitian Purwanti \& Kalbuana (2016) yang menyatakan bahwa kepemilikan institusional tidak berpengaruh terhadap completeness of financial statement disclosure, namun tidak sejalan dengan penelitian Sinurat \& Sembiring (2016) yang menyatakan bahwa kepemilikan institusional berpengaruh terhadap completeness of financial statement disclosure.

\section{Tipe Auditor terhadap Completeness $O f$ Financial Statement Disclosure;}

Hasil penelitian menunjukkan bahwa auditor hanya sebatas memberi opini dan kewajaran atas laporan keuangan sehingga baik perusahaan yang menggunakan jasa audit big four dan afiliasinya serta perusahaan yang menggunakan jasa audit non big four dan afiliasinya tidak berpengaruh pada semakin lengkapnya pengungkapan laporan keuangan karena umumnya perusahaan menganggap informasi yang diungkapkan secara penuh memiliki dampak buruk bagi perusahaan misalnya berbahaya bagi pesaing industri sejenis serta berbahaya jika informasi tersebut merupakan kunci penting dari suatu perusahaan, di sisi lain peran auditor tidak 
terfokus pada lengkapnya pengungkapan pada laporan keuangan.

Hal ini dibuktikan dengan PT. WASKITA BETON PRECAST Tbk (WTON) yang memiliki skor completeness of financial statement disclosure paling tinggi yaitu sebesar 0,9726 atau 97,26\% pada tahun 2017 dan memakai jasa audit KAP non big four dan afiliasinya, selain itu pada PT. CHITOSE INTERNATIONAL Tbk (CINT) juga memiliki skor completeness of financial statement disclosure yang tinggi sebesar 0,9589 atau 95,89\% pada tahun 2018 dan memakai jasa audit KAP non big four dan afiliasinya. Hal lain dapat dibuktikan pada PT. ASIAPLAST INDUSTRIES Tbk (APLI) yang diaudit oleh KAP big four dan afiliasinya tetapi hanya memiliki skor completeness of financial statement disclosure sebesar 0,6849 atau hanya 68,49\% pada tahun 2018 serta pada PT. GOODYEAR INDONESIA Tbk (GDYR) yang juga diaudit oleh KAP big four dan afiliasinya tetapi hanya memiliki skor completeness of financial statement disclosure sebesar 0,6712 atau 67,12\% pada tahun 2017.

Situasi tersebut dapat disimpulkan bahwa kelengkapan pengungkapan laporan keuangan tidak bergantung pada reputasi auditor yang mengaudit karena peran auditor memastikan bahwa laporan keuangan disajikan secara wajar dan bebas kesalahan material sehingga tidak berpengaruh pada transparansi perusahaan untuk mengungkapkan laporan keuangan secara lengkap. Hal ini sejalan dengan penelitian Agyei (2012), Puspita et al. (2015), Hau \& Danh (2017) yang menyatakan bahwa tipe auditor tidak berpengaruh terhadap completeness of financial statement disclosure, namun berlawanan dengan penelitian dari Shehata et al. (2014), Mahayana \& Bagiada (2015) dan Hidayat (2017) yang menyatakan bahwa tipe auditor memiliki pengaruh terhadap completeness of financial statement disclosure.

Ukuran Perusahaan
Completeness Of Financial Statement
Disclosure

Hasil penelitian menunjukkan bahwa semakin besar total aset perusahaan maka perusahaan akan semakin lengkap dalam mengungkapkan laporan keuangannya terlebih jika perusahaan berkepentingan pada penambahan modal kerja dan membutuhkan dana dari pihak ketiga karena sebagai salah satu pertimbangan kreditur adalah karakteristik perusahaan salah satunya ukuran perusahaan yang dapat dilihat dari total aset sehingga perusahaan akan lebih lengkap dalam mengungkapkan laporan keuangannya selain itu perusahaan dengan ukuran yang besar juga cenderung menjadi perhatian publik sehingga publik menuntut untuk perusahaan lebih transparan dan lengkap dalam mengungkapkan laporan keuangan.

Hal ini dibuktikan dengan PT. ASTRA INTERNATIONAL Tbk (ASII) yang memiliki total aset paling tinggi yaitu sebesar 33.4737 atau Rp. 344.711.000.000.000 dan memiliki skor completeness of financial statement disclosure sebesar 0,9452 atau 94,52\% pada tahun 2018 dan juga pada PT. KRAKATAU STEEL Tbk (KRAS) yang memiliki total aset sebesar 31,7621 atau Rp. 62.243,942.958.000 dan memiliki skor completeness of financial statement disclosure sebesar 0,9041 atau 90,41\% pada tahun 2018. Situasi tersebut dapat disimpulkan bahwa semakin besar ukuran perusahaan maka perusahaan tersebut akan semakin menjadi sorotan publik untuk lebih lengkap dalam mengungkapkan laporan keuangannya. Hal ini sesuai dengan penelitian Fitriani et al. (2016), Sefty \& Farihah (2016), Neliana (2017), Larasati et al. (2018) yang menyatakan bahwa ukuran perusahaan berpengaruh terhadap completeness of financial statement disclosure, namun berlawanan dengan penelitian Puspita et al. (2015), Purwanti \& Kalbuana (2016) dan Fitriyanti et al. (2017) yang menyatakan bahwa ukuran perusahaan tidak berpengaruh terhadap completeness of financial statement disclosure.

\section{Umur Perusahaan terhadap Completeness of Financial Statement Disclosure}


Hasil penelitian menunjukkan semakin tinggi umur perusahaan membuat completeness of financial statement disclosure semakin turun karena semakin lama umur perusahaan belum tentu akan lebih lengkap dalam mengungkapkan laporan keuangan, hal ini karena semakin lama perusahaan berdiri maka biaya-biaya yang dikeluarkan akan lebih besar termasuk juga biaya untuk mengungkapkan informasi-informasi tersebut oleh sebab itu perusahaan yang berumur lebih lama akan mengungkapkan informasi yang dianggap banyak disorot oleh para investor dengan tujuan untuk tetap menarik investor.

Hal ini dibuktikan dengan PT. GOODYEAR INDONESIA Tbk (GDYR) yang telah berumur 37 tahun dan memiliki skor completeness of financial statement disclosure sebesar 0,6712 atau 67,12\% pada tahun 2017dan juga pada PT. WASKITA BETON PRECAST Tbk yang baru berumur 1 tahun dan memiliki skor completeness of financial statement disclosure paling tinggi sebesar 0,9726 atau 97,26\%. Situasi tersebut membuktikan bahwa semakin lama umur perusahaan maka tingkat completeness of financial statement disclosure semakin turun dan sebaliknya perusahaan yang baru di pasar modal maka tingkat completeness of financial statement disclosure semakin tinggi. Hal ini sesuai dengan penelitian Wahyuningsih (2016), Bambang \& Ahmad (2017) dan Fitriyanti et al. (2017) yang menyatakan bahwa umur perusahaan berpengaruh terhadap completeness of financial statement disclosure, namun berlawanan dengan penelitian dari Halim \& Sampurno (2015) dan Astina (2017) yang menyatakan bahwa umur perusahaan tidak berpengaruh terhadap completeness of financial statement disclosure.

Leverage, Strukture Perusahaan, Tipe Auditor, Ukuran Perusahaan Dan Umur Perusahaan terhadap Completeness of Financial Statement Disclosure;

Berdasarkan hasil penelitian secara simultan seluruh variabel dalam penelitian ini berpengaruh terhadap completeness of financial statement disclosure. Penelitian ini mendukung penelitian sebelumnya yang dilakukan oleh (Putri Karuniasari, 2013) dengan judul pengaruh leverage, profitabilitas, dan ukuran perusahaan terhadap luas pengungkapan laporan keuangan pada perusahaan manufaktur yang telah terdaftar di Bursa Efek Indonesia (BEI).

\section{KESIMPULAN DAN SARAN}

\section{Kesimpulan}

1. Variabel leverage yang diukur menggunakan rasio total utang terhadap total aset tidak berpengaruh signifikan terhadap completeness of financial statement disclosure;

2. Variabel struktur kepemilikan yang diukur menggunakan kepemilikan institusional tidak berpengaruh signifikan terhadap completeness of financial statement disclosure;

3. Variabel tipe auditor yang diukur menggunakan data dummy tidak berpengaruh signifikan terhadap completeness of financial statement disclosure;

4. Variabel ukuran perusahaan yang diukur menggunakan total aset yang di transformasi ke dalam logaritma natura berpengaruh positif signifikan terhadap completeness of financial statement disclosure;

5. Variabel umur perusahaan yang diukur berdasarkan tahun IPO dikurangi dengan tahun sampel penelitian berpengaruh negatif signifikan terhadap completeness of financial statement disclosure;

6. Leverage, strukture perusahaan, tipe auditor, ukuran perusahaan dan umur perusahaan terhadap completeness of financial statement disclosure.

\section{Saran}

1. Bagi penelitian selanjutnya diharapkan dapat menambahkan variabel lain yang berpengaruh terhadap Completeness of 
Financial Statement Disclosure seperti profitabilitas, kepemilikan publik, kepemilikan manajerial dan lainnya;

2. Diharapkan bagi para kreditur dalam pengambilan keputusan tetap harus memperhatikan informasi yang diungkapkan oleh perusahaan. Hal tersebut sebagai bahan evaluasi serta pertimbangan dalam mengetahui risiko-risiko yang dihadapi perusahaan maka akan memudahkan kreditor dalam pengambilan keputusan dalam negosiasi pemberian kredit;

3. Hasil penelitian menunjukkan bahwa tingkat kepatuhan perusahaan manufaktur sudah berada di atas 60\% tetapi masih harus ditingkatkan. Untuk pihak perusahaan disarankan lebih baik dalam melakukan pengungkapan informasi dan disarankan mengungkapkan informasi yang memang benar terjadi dalam perusahaan agar informasi yang diungkapkan tidak menyesatkan penggunanya;

4. Untuk pihak pemerintah disarankan dapat mempertegas sanksi terhadap perusahaan yang masih belum memenuhi pengungkapan wajib. Di samping itu pemerintah harus terus memperketat dan menambahkan item-item yang harus diungkapkan mengingat kondisi bisnis yang semakin berubah-ubah dan tidak pasti ditambah lagi tantangan dalam menghadapi adanya revolusi industri 4.0.

\section{Daftar Pustaka}

Abidin, F. (2019). Akibat Overstated Lapkeu OJK Sanksi Hanson International 5,6M. Diakses 14 Agustus 2019, dari https://www.idxchannel.com/marketnews/akibat-overstated-lapkeu-ojksanksi-hanson-international-rp56miliar

Ananda, R. R. (2015). Pengaruh Kepemilikan Keluarga, Kepemilikan Manajerial, Dewan Komisaris, Komite Audit Dan Auditor Eksternal Terhadap Luasnya Pengungkapan di Laporan Tahunan. Jom FEKON Vol.2 No.2 .

Astina, J. (2017). Faktor-Faktor Yang Mempengaruhi Kelengkapan Pengungkapan Laporan Keuangan Pada
Perusahaan Manufaktur Yang Terdaftar Di Bei Periode 2011-2013.JOM FEKON. VOL.4.No.1

Ayu, I., \& Devi, S. (2014). Pengaruh Ukuran Perusahaan, Likuiditas, Leverage Dan Status Perusahaan Pada Kelengkapan Pengungkapan Laporan Keuangan. EJurnal Fakultas Ekonomi dan Bisnis Universitas Udayana ( Unud ), Bali , Indonesia3, 474-492. ISSN 2302-8556.

Bambang S. Ahmad R. (2017). Faktor - Faktor Yang Menentukan Kelengkapan Pengungkapan Laporan Keuangan Perusahaan.Jurnal Ekubis Vol. 1 No. 2. ISSN 2541-1950

OJK, (2016). Peraturan OJK No.29 POJK 04 Tentang Laporan Tahunan Emiten atau Perusahaan Publik.

Ben K. Agyei-Mensah. (2012). Corporate Financial Reporting: Firm Characteristics And The Use of Internet As A Medium of Communication By Listed Firms In Ghana. African Journal Of Business Management, 6(6). https://doi.org/10.5897/ajbm11.1854

Dien, S., Iftahul F. (2016). Pengaruh Ukuran Perusahaan dan Kepemilikan Manajerial Terhadap Pengungkapan Laporan Keuangan. Jurnal Akuntansi Vol. 3.No. 2. ISSN 2339-2436

Fitriani, M. P., Fadilah, S., \& Nurcholisah, K. (2016). Pengaruh Ukuran Perusahaan, Likuiditas dan Leverage Terhadap Pengungkapan Laporan Keuangan. Prosiding Akuntansi . ISSN 2460-6561.

Fitriyanti, I. N., Norita, \& Aminah, W. (2017). Analisis Pengaruh ROE, Leverage, Ukuran Perusahaan dan Umur Perusahaan Terhadap Kelegkapan Pengungkapan Laporan Keuangan (Studi Pada Perusahaan Farmasi Yang Terdaftar Di Bei Tahun 2011-2015.Vol. 4 No.2 , 1603 ISSN 2355-9357.

Halim, M. (2015). No Title. Faktor - Faktor Yang Mempengaruhi Kelengkapan Laporan Keuangan (Studi Pada Perusahaan Manufaktur Yang Terdaftar Di Bei) Periode 2012 - 2014. Jurnal Manajemen Bisnis. Vol.1.No.2. 261-280. Hau, L. L., \& Danh, L. C. (2017). Determinants of Corporate Disclosure in Financial 
Statements : Evidence from Vietnamese Listed Firms. (January). https://doi.org/10.24001/ijaems.3.5.11

Hery. (2014). Analisis Laporan Keuangan. Jakarta:Grasindo.

Hidayat, M. (2017). Faktor-Faktor Yang Mempengaruhi Pengungkapan Sukarela Pada Laporan Tahunan Sektor Perbankan Di Bei.Dimensi Vol. 6 No.1, 151-172 ISSN 2085-9996.

Hmoud, M., Alqaraleh, S., \& Ahmad, N. (2018). The Impact of the Board of Directors Characteristics on the Completeness of Financial Reports in Jordan The Impact of the Board of Directors Characteristics on the Completeness of Financial Reports in Jordan. 8(11), 151-159. https://doi.org/10.6007/IJARBSS/v8i11/4891

Jensen, C., \& Meckling, H. (1976). Theory Of The Firm: Managerial Behavior, Agency Costs And Ownership Structure I . Introduction and summary In this paper WC draw on recent progress in the theory of ( 1 ) property rights, firm . In addition to tying together elements of the theory of e. 3, 305-36o.

Larasati, H., Suzan, L., Dillak V. (2018). Pengungkapan Laporan Keuangan: Ukuran Perusahaan, Likuiditas, Leverage Dan Profitabilitas (Survei Pada Perusahaan Pertambangan Yang Terdaftar Di Bursa Efek Indonesia Tahun 2014-2016), Vol.5 No.1, 852.

Mulia A. \& Ida.(2018). Faktor-Faktor Yang Mempengaruhi

Pengungkapan

Kelengkapan Laporan

Keuangan.Jurnal Manajemen Bisnis Vol. 7.No. 2.ISSN 2302-3449.

Neliana, T. (2017). Faktor-Faktor Yang Mempengaruhi Tingkat Kelengkapan Pengungkapan Laporan Keuangan.Jurnal Riset Akuntansi Dan Keuangan, 5 (2), 1409 - 1422.ISSN 2541o61xxx.

Ririh Dian. (2015). Faktor-Faktor Yang Mempengaruhi Kelengkapan Pengungkapan Laporan Keuangan.Jurnal Dinamika Akuntansi Vol. 7.No. 1.85-97. ISSN 2085-4277.
Sinurat, D \& Sembiring, E.. (2016). Pengaruh Profitabilitas, Leverage, Struktur Kepemilikan Dan Status Perusahaan Terhadap Pengungkapan Laporan Keuangan Pada Perusahan Manufaktur Yang Terdaftar Di Bursa Efek Indonesia (Hal. 63-82). 2(1), 63-82. ISSN 24431079

Sugianto, D. (2019). Terbukti Manipulasi Laporan Keuangan Benny Tjokro Didenda 5M. Diakses 12 Agustus 2019, dari https://finance.detik.com/bursadan-valas/d-4658394/terbuktimanipulasi-laporan-keuangan-bennytjokro-didenda-rp-5-m.

Suryanto. (2017). Determinants of Disclosure Completeness Of Financial Statements An Empirical Study In Indonesia. Department of Business Administration, Universitas Padjadjaran.5(2), 18-28.

Suwardjono.(2016). Teori Akuntansi Perekayasaan Pelaporan Keuangan. Yogyakarta: Bpfe Yogyakarta.

Titik P., Nawang K. (2016). Pengaruh Profitabilitas, Likuiditas, Leverage, Ukuran Perusahaan, dan Kepemilikan Institusional terhadap Financial Statement Disclosure Bank Pembangunan Daerah Di Indonesia. (97), 12-23.

Wahyuningsih, Arifati, D., \& Raharjo.(2016). Pengaruh Likuiditas, Leverage, Profitabilitas, Porsi Saham Publik, Ukuran Perusahaan Dan Umur Perusahaan Terhadap Kelengkapan Pengungkapan Laporan 